\title{
Sustainable Pathways Out of Rural Poverty in Ethiopia: Scoping Review for Priority Setting
}

\author{
Tsegaye Molla \\ Department of Agricultural Economics, DebreMarkos University, Ethiopia
}

\begin{abstract}
Poverty, food insecurity, hunger, and malnutrition are global challenges contained within the 17 sustainable development goals (SDGs) requiring countries' priority setting to realize by 2030. Achieving the full range of aforementioned SDGs by 2030 requires a combination of pro-poor investments in sustainable agriculture, rural development, and social protection measures to continually lift people out of chronic undernourishment and poverty from rural areas where the world's largest hungry and poor are living. Aggregating previous poverty studies done at household level, it is found that leveraging at human capital formation and financial resources are paramount pathways out of poverty followed by social/institutional capabilities. Hence, the strategies of poverty targeting has to be revisited based upon livelihood capitals based priority setting to tap untouched differential livelihood potentials and redirecting future interventions as pro-poor to keep sustainable poverty reduction policies and programs getting sustainable and addressing the poor population of the country.
\end{abstract}

Keywords: poverty, SDGs, Priority setting, Sustainable poverty reduction

DOI: $10.7176 / \mathrm{JESD} / 10-9-04$

Publication date:May $31^{\text {st }} 2019$

\section{Introduction}

Poverty with different forms is still a worldwide social problem even in the $21^{\text {st }}$ century (FAO, 2012). Poverty in African countries is a longstanding problem affecting a significant portion of its rural and urban population (MoFED, 2012). Forging ahead the battle against global challenges of food insecurity, hunger, malnutrition, and poverty while promoting sustainable agriculture are among 17 sustainable development goals(SDGs) we seek to realize by 2030 (FAO, 2015). Achieving the full range of aforementioned SDGs by 2030 requires a combination of pro-poor investments in sustainable agriculture, rural development, and social protection measures to continually lift people out of chronic undernourishment and poverty from rural areas where the world's largest hungry and poor are living (FAO, 2015). There is a declining trend of poverty in Ethiopia both at regional and national levels as a result of efforts done by development plans intervention and implementation so far though they lack fair distribution of resources to keep it sustainable and having multiplied socio-economic impacts at large.

For sustainable poverty reduction to proceed and realization of poverty free Ethiopia, there is a need to design pro-poor poverty reduction policies and strategies though it is going on since ten years ago. Hence, for ease of intervention and to succeed in the near future, it entails deep assessment and review of poverty policies and programs implemented so far in terms of livelihood capitals alongside of potentials of the country. This review paper is based up on livelihood capitals based priority setting to sustain poverty reduction efforts from studies documented with special focus on rural areas of the country. This review is, thus, deemed to fill the existing poverty policy and program implementation gaps with studies done and published with a scope covering household level poverty analysis at rural areas of the country.

\section{Pathways Out of Rural Poverty}

\subsection{Determinants of Poverty in the Developing World}

Poverty may be due to national, sector-specific, community, household, or individual characteristics. Some of the factors "causing poverty" can best be summarized by region, community, household, and individual characteristics (WBI, 2005). Identification of the determinants of poverty is based on two cautions put here under. The first one is the difficulty of separating causation from correlation. For instance, we know that poor people tend to have low levels of education; but are they poor because they have little education, or do they have little education because they are poor? Here, a statistical association alone is not enough to establish causality, and additional information is likely required to go deep in to the nature of association. Second, most of the "causes" of poverty which are identified here are immediate (or "proximate") causes, but not necessarily "deep" causes. For instance, suppose that we can demonstrate that low levels of education do indeed increase the risk of poverty. This is interesting, but now begs the question of why some people have low levels of education in the first place: Were the school fees too high? Was there no school nearby? Was the quality of the education abysmal? Were their parents unsupportive, or even hostile to education? Was there a concern that an educated woman could not find a husband?

Among the key causes or at least correlates of poverty, some of them are identified as:

a) Region-level characteristics: include vulnerability to flooding or typhoons, remoteness, quality of governance, and property rights and their enforcement. 
b) Community-level characteristics: include the availability of infrastructure (roads, water, and electricity) and services (health, education), proximity to markets, and social relationships.

c) Household and individual characteristics: among the most important of which are:

- Demographic, such as household size, age structure, dependency ratio, gender of head

- Economic, such as employment status, hours worked, property owned

- Social, such as health and nutritional status, education, shelter.

\subsection{Household Level Pathways Out of Rural Poverty in Ethiopia}

Undoubtedly, reducing or eradicating poverty once and for all is the starting point for a nation to embark on overall economic growth and development. This would be possible through designing appropriate poverty reduction strategies accordingly which in turn entails to identify who the poor are, to what extent they are impoverished, and what factors are antidotes to and underpinning poverty in their areas. Because there is no reason to believe that the root causes of poverty are the same everywhere, country-specific analysis is essential. Hence, investigating the proximate causes of poverty in rural areas of Ethiopia is deemed necessary as it sparks light on which factors and how to intervene reliably and with appropriate priority setting.

Following the convention that poverty is better analyzed provided that all measures of poverty rely on a household as their unit of analysis (WBI, 2005; Ashley, 2011), the determinants of rural poverty discussed here are limited to household characteristics alone putting households in either side of the dichotomy of poverty according to a pre-determined poverty line (determining them to be either poor or non-poor). As poverty is multidimensional, it can be reduced by increasing people's livelihood assets (social, physical, human, financial and natural) (Sunethra, 2013). Hence, the key correlates of rural poverty having major influence on the wellbeing, livelihood options and strategies of rural households (Adugna \& Wagayehu, 2013; Joseph et al., 2005) can be categorized under five fundamental livelihood capitals as identified by DFID (2000) inclusive of other attributes associated with each livelihood capital.

\subsubsection{Human capitals}

Although human capital is a very widely used term with various meanings in the field of development studies, in the context of the sustainable livelihood framework it is defined as follows: "Human capital represents the skills, knowledge, ability to labor and good health that together enable people to pursue different livelihood strategies and achieve their livelihood objectives" (DFID, 2000). It is the quality of knowledge and amount of labor resources available for rural households including other household attributes like age of head, headship, marital status and dependency ratio that co-determine their poverty status.

The significance of education as a way of fighting poverty (UNESCO, 2001a cited in Aitufe\&Oriahi, 2010) with extension service delivery is paramount as households better understand and pursue relevant livelihood options against poverty (Ayalnehet al., 2005; Hilina, 2005; Semere, 2008 and Adugna\&Wogayehu, 2012). Healthiness, which is an antidote of poverty, enables households to engage with much strength in productive livelihood activities thus exit rural poverty (Metalign, 2005) as it is highly correlated with other human capital attributes (Adugna and Wogayehu, 2013). Further, a household with large family size, headed by female and with large number of dependents increases the probability of falling under poverty than those with fewer family size, headed by males and with lower dependents (Ayalnehet al., 2005; Hilina, 2005 and Adugna, 2012). The age of household heads also influences their household to exit from or to fall in to poverty. Hilina (2005) indicated that as the head is getting old-aged, this results with larger children and being weaker to function properly in income generating livelihood activities; hence, making the household poor whereas Fistum and Holden (2000), Semere (2008) and Adugna (2012) justified old-aged household heads are able to accumulate more wealth, coupled with acquiring more experiences, fostering to exit from rural poverty.

\subsubsection{Physical capitals}

Physical capital comprises the basic infrastructure and producer goods needed to support livelihoods (DFID, 2000). Rural households who raise large size livestock serves them as a hedge against unforeseen risks of food insecurity and falling under chronic poverty through pursuing diversified farming; hence, a way for immediate recovery to their pre-shock state (Bilusie\&Issac, 2010; Dercon, 1999) provided that it is accompanied with reasonable land size and oxen holding, farm input use and proximity to the nearest market place, all weather roads (Adugna\&Sileshi, 2013; Semere, 2008 and Dereje, 2008). Because, it is apparent that rural households' exit from poverty is the interplay result of proximity to markets and roads to purchase farm inputs and sale farm and nonfarm products produced from the efficient utilization of land resources with oxen and human labor as complements and land resource with livestock as supplements respectively. Besides, having one's own house, access to and proximity to potable water, education and health centers are highly significant determinants of household's wealth and livelihood options, hence their poverty status (Adugna\&Wagayehu, 2013).

\subsubsection{Natural capitals}

Natural capital is the quality and quantity of natural resource stocks and environmental services from which resource flows and services (hydrological cycle, nutrient cycling, erosion protection, pollution sink) useful for 
livelihoods are derived (Scoones, 1998; DFID, 2000 and Lasse, 2001). The most imperative and probably the lifeblood of the rural community available for them is endowment of land resources marking them off either poor or non-poor in the dichotomy of rural poverty. It is an asset of enormous importance for billions of rural dwellers in the developing world including Ethiopia (Dercon, 1999; Toulmin et al., 2006) although pressure on it is set to increase from continued population growth and climate change. Adequate land holding alone is not a guarantee for poverty-free household unless it is fertile and productive. Hence, rural households endowed with fertile land produce a range of cash crops for generating financial capital from farm (Ajala, 2010), produce food crops with more diversification (Dercon 1999; Dercon, 2002) leading them to food self-sufficiency ultimately exit rural poverty (Alemayehu et al., 2006; Dawit et al., 2011; Adugna \& Sileshi, 2013).

\subsubsection{Financial capitals}

Financial capital denotes a range of financial resources embracing cash availability and regular and irregular inflows of money enabling people to adopt different livelihood strategies and hence to achieve their livelihood objectives (DFID, 2000). Financial capital consists of major income sources available for rural households like farm income, off-farm/non-farm income, access to credit and remittances. Credit markets remain ways to invest in small agricultural business and an important shock coping mechanisms, hence significant for poverty reduction (Metalign, 2005; Alemayehu et al., 2006) attesting the importance of financial development. Because, microfinance allows people to pursue diversified sources of income (start new enterprises and expand existing ones) and to shield themselves against unforeseen external shocks (Bamlaku, 2006). Besides, rural saving habits are antidotes against rural poverty despite its difficulty for many of the people to generate it (Adugna \& Wagayehu, 2013; Metalign, 2005). Off-farm/non-farm activities are also providing employment for the rural people during the slack season (Dawit et al., 2011; Dercon, 1999) insisting their promotion at large to tackle rural poverty.

\subsubsection{Social capitals}

Social capitals are social resources (networks, social claims, social relations, affiliations, associations) upon which people draw when pursuing livelihood strategies requiring coordinated actions (Scoones, 1998; DFID, 2000). Social capital reflects the patterns and systems of social organizations that facilitate or constrain co-operative enterprise, inter-household relations and individual entitlements. It includes formal and informal organizations and networks ranging from community based organizations to religious groups to neighbors who help each other out by sharing farm implements, land, oxen and human labor, food, money etc (Hellin et al., 2003). Membership to cooperatives, share-cropping, share-rearing, oxen-sharing, social leadership participation and labor-sharing arrangements are among typical social capitals for rural people (Dercon, 1999; Adugna \& Wagayehu, 2013) to stand in coordination against socio-economic problems surrounding them, hence reducing the likelihood of falling under poverty. Further, ekub, eddir and kinship are paramount social capitals within the rural community.

\section{Conclusion and Policy Suggestions}

Keeping a statistically organized poverty profile is deemed indispensible for it substantiates major facts on poverty and patterns of poverty; therefore, it facilitates poverty reduction efforts and to act accordingly. Hence, targeting at the poor (domestically or worldwide) and monitoring and evaluating pro-poor projects and policies would only be possible if adequate poverty profile is existent in a country as any possible pro-poor intervention comes after knowing who the poor are and what makes them to stay with or exit out of poverty.

Poverty in Ethiopia shows a trend of reduction since the mid 1990's. For Ethiopia to realize the targets of SDGs (Sustainable Development Goals), priority should be given to building human capital accompanied with financial capitals. To date, Ethiopia is in a transformational path towards SDG1, but attention has to be given to prioritize and fairly distribute livelihood capitals based up on potentials across nationwide. Although it is certain that economic growth and poverty are strongly and negatively correlated ${ }^{1}$, one can't tell as if poverty is reduced unless income/consumption inequality across the population is narrowed via equitable economic growth rate on behalf of creating better off rural households.

Moreover, poverty reduction in rural areas will be realized from improved access and optimal combination of the five fundamental livelihood capitals viz. human capital, physical capital, natural capital and social capital provided that their association with rural poverty is treated accordingly. Rural poverty will be reduced to a greater extent if rural households have improved access to livelihood capitals. Because, accessing the proper mix of capitals imply pursuing better livelihood strategy, thus, exit poverty whereas lacking them meant staying under poverty- calls for promoting increased and improved access to livelihood capitals in a way that improves the living standard of rural households thereby establishing poverty free rural community ultimately.

\section{References}

Adugna, E., and Sileshi, M., (2013). Determinants of poverty in agro-pastoral societies of Southern

${ }^{1}$ See "Dynamics of Growth and Poverty in Ethiopia (MoFED, 2008)" a survey conducted based on HICES, WMS and PPA substantiating economic growth elasticity of poverty. Accordingly, a 1\% per capita GDP increase will result in a $1.7 \%$ decrease in the poverty head count index. Based on this elasticity relationship, it is calculated that the poverty head count ratio have declined to $29.2 \%$ by the end of $2009 / 10$. 
Ethiopia. Livestock Research for Rural Development, 25(20): http://www.lrrd.org/lrrd25/2/adug25020.htm.

Adugna, E., and Wagayehu, B., (2013). Analysis of Wealth and Livelihood Capitals in Southern Ethiopia: A Lesson for policy makers. Current Research Journal of Social Sciences 5(1): pp.1-10, 2013.

Adugna, E., (2012). Determinants of Livelihood Diversification in Pastoral Societies of Southern Ethiopia. Journal of Agriculture and Biodiversity Research. 1(3); pp. 43-52: http://www.onlineresearchjournals.org/JABR.

Aitufe, A.O., and Oriahi, C.I., (2010). Education for the Eradication of Poverty. Current Research Journal of Social Sciences 2(6): 306-310, 2010. Institute of Education at Ambrose Alli University, Ekoma, Edo State, Nigeria.

Ajala, O.A., (2010). Livelihoods Pattern of "Negede Weyto" Community in Lake Tana Shore, Bahir Dar, Ethiopia. Ethiopian Journal of Environmental Studies and Management, 1(1): pp.19-30; March. 2008.

Ashley, P., (2011). Unit of Analysis for Poverty Measurement: Comparison of the Supplemental Poverty Measure and the Official Poverty Measure. U.S Census Bureau.March 2011.

Ayalneh, B., Konard, H., and Benedikt, K., (2005). Determinants of Poverty in Rural Ethiopia, Quarterly Journal of International Agriculture, 44 (2): pp.101-120. DLG -Verlag Frankfurt / M.

Bamlaku, A., (2006). Microfinancing and Poverty in Ethiopia: A Paper prepared under the Internship Program of IDRC, ESARO, Nairobi, 2006.

Bilusie, B., and Issac, P., (2010). An Assessment of Rural Poverty: The Case of Selected Kebeles of Shashemane Woreda, Ethiopia. Journal of Sustainable Development in Africa. 12(4): pp.270-280. Clarion University of Pennsylvania, Clarion, Pennsylvania.

Dawit, A., Woldeamlak, B., Gete, Z., Yemisrach, A., and Peter T., (2011). Extent and Determinants of Household Poverty in Rural Ethiopia: A Study of Six Villages; Eastern Africa Journal of Social Science Research Review, 27(2): pp. 21-49. http://muse.jhu.edu/journals/eas/summary/v027/27.2.alemu.html.

Dercon, S., (1999). Ethiopia: Poverty Assessment Study. A Revised Version of a Report for IFAD.

Dercon, S., (2002). "Income risk, coping strategies and safety nets". The World Bank Research Observer, 17(2): pp. 141-166.

Dereje, Z., (2008). Determinants of Poverty in Rural Dire Dawa Administration, Eastern Ethiopia. Msc thesis in Agricultural Economics. Haramaya University. October 2008.

DFID, (2000). Sustainable Livelihoods Guidance Sheets. Department for International Development. Retrieved from: http://www.livelihood.org/info/info_guidancesheets.htm.

Food and Agricultural Organization (FAO), (2012). World Poverty, A Look at Causes and Solutions; by Vincent Wilmot; 166 Freeman Street; Grimsby, UK.

Food and Agricultural Organization (FAO), (2015). ). FAO and the 17 Sustainable Development Goals, 1-8.

Hellin, J., Rodriguez, D. and Coello, J., (2003). Measuring the livelihood impact of farmer-to-farmer extension services in the Andes region. Peru.http://www.sed.manchester.ac.uk/research/iarc/ediais/pdf/Hellin.pdf.

Hilina, M., (2005). Dimensions and Determinants of Poverty in Pastoral areas of Eastern Ethiopia; the case of Shinile zone in Somali National Regional State, M.sc thesis, Alemaya University. April 2005.

Joseph, O., Patricia, K., Maren, R., Isabelle, B. and An, N. (2005). Livelihood mapping and poverty correlates at a meso-level in Kenya. International Livestock Research Institute (ILRI), Nairobi, Kenya; Food Policy30 (2005) pp. 568-583.http://www.elsevier.com/locate/foodpol.

Lasse, K., (2001). The sustainable Livelihood Approach to Poverty Reduction: An introduction. Swedish International Development Agency (SIDA). February 2001.

Metalign, A., (2005). Rural poverty situation and determinants: The case of KersaKondalitityWoreda, South West Shewa. M.A degree thesis at the Institute of Regional and Local development Studies, Addis Ababa University.

MoFED (Ministry of Finance and Economic Development), (2008). Ethiopia: Dynamics of Growth and Poverty in Ethiopia (1994/95-2004/05). Addis Ababa, Federal Democratic Republic of Ethiopia.

MoFED (Ministry of Finance and Economic Development), (2012). Interim Report on the 2010/11 Poverty Analysis. Addis Ababa: Federal Democratic Republic of Ethiopia.

Semere, G., (2008). Dimensions and Determinants of Rural Household Poverty: The Case of Eastern Zone, Tigray National Regional State.

Scoones, I., (1998). Sustainable Rural Livelihoods: A Framework for Analysis. IDS (Institute of Development Studies) Working Paper 72, 1998.

Sunethra, T., (2001). Rural Livelihood Strategies and the Five Capitals: A Comparative Study in the Selected Villages of Sri Lanka. http://www.sasnet.lu.se/EASASpapers/20.

Toulmin, C., Cotula, L. and Quan, J., (2006). Better Land Access for the Rural Poor: Lessons from Experience and Challenges Ahead. Presented at the International Conference on Agrarian Reform and Rural Development (ICARRD), organized by FAO.IIED, FAO.

WBI (World Bank Institute), (2005). Introduction to Poverty Analysis; Poverty Manual, All, JH Revision: pp.70 $-71$. 